\title{
Thresholds of Environmental Physical Resilience of Tehran Metropolis
}

\author{
Ismail Abdoli ${ }^{1} \mathbb{D}, \underline{\text { Manijeh Ghahroudi Tali }}{ }^{2} \mathbb{D}$, Jamileh TavakoliNia ${ }^{3}$
}

Date of submission: 17 Nov. 2020 Date of acceptance: 11 Mar. 2021

\begin{abstract}
INTRODUCTION: The structure of the urban platform of Tehran and its physical characteristics depends on the inherent conditions and environmental thresholds in relation to changes. This study aimed to determine the natural landscapes of Tehran by two phenomena of earthquake and flood that posed the highest risk in different periods of this city. Therefore, the natural perspective of Tehran is divided into three perspectives of north, central, and south regarding the inherent features and evolutionary process.

METHODS: The relationship between the perspective of Tehran based on the form and geomorphological processes and the evaluation of earthquake and flood hazards have been observed in four stages, which included data collection, data processing, calculation of indicators, and analysis of findings. The studied area was divided into three northern, central, and south urban landscapes to determine the resistance thresholds of the city according to the characteristics of topography, physiography, geology, the results of field studies and satellite images, aerial photographs, as well as paleogeomorphological research in Tehran.

FINDINGS: According to the zoning map of Tehran based on the earthquake phenomenon in three perspectives of north, center, and south, the highest distribution of non-resistance is observed in the northern and southern areas of the city. Northeast, southwest, and semi-western regions have the highest urban resilience to earthquakes.

Moreover, regarding the zoning of Tehran based on the flood phenomenon in the three perspectives of north, center, and south, the highest distribution of non-resilience has been observed in the northern regions of the city. Northeast, southwest, and west of Tehran have the highest urban flood resilience.

CONCLUSION: Based on the results of the present study, in order to increase resilience against the risks of earthquakes and floods, the city of Tehran should be studied not in just one perspective but in different perspectives.
\end{abstract}

Original Article

Keywords: Earthquake; Flood; Tehran; Urban Perspective; Resilience

How to cite this article: Abdoli I, Ghahroudi Tali M, TavakoliNia J. Thresholds of Environmental Physical Resilience of Tehran Metropolis. Sci J Rescue Relief 2021; 13(1): 16-30.

\section{Introduction}

ne of the problems that constantly threatens human societies is the occurrence of disasters and accidents that cause irreparable damage to various aspects of human life including residential, socio-economic, and biological, and psychological areas if there is no prior preparation for them (1). With the rise of global urbanization, the role of the city has become paramount in economic and social development; however, frequent natural events and disasters pose a serious threat to the urban system (2).

It is necessary to improve the resilience of urban systems as a long-term mechanism to improve social welfare and achieve sustainability (3). Resilient cities are stable networks of physical elements and human societies. Physical elements are formed as the main components of the

\footnotetext{
1-PhD student, Geomorphology, Faculty of Earth Sciences, Shahid Beheshti University of Tehran, Tehran, Iran

2-Professor, Geomorphology, Faculty of Earth Sciences, Shahid Beheshti University of Tehran, Tehran, Iran

3-Associate Professor, Geography and Urban Planning, Faculty of Earth Sciences, Shahid Beheshti University of Tehran, Tehran, Iran

Correspondence to: Manijeh Ghahroudi Tali, Email: m-ghahroudi@sbu.ac.ir
} 
physical structure of the city on its natural bed (soil, topography, geography) (4). The improvement of compatibility, resilience, and recovery of cities has turned into an important issue in the field of disaster management (5). Resilience has received widespread attention as a new research model in the field of safety and protection $(6,7)$.

Researchers distinguish between two definitions of resilience, including processoriented and consequential, as well as between two types of resilience, including inherent and adaptive resilience. Inherent resilience is preevent resilience in the community. This type of resilience is often used as a basis for the measurement of the occurred outcomes and changes over time. Adaptive resilience is the ability of individuals or communities, to learn and respond to predicted changes through certain risk events. This process usually involves social learning; however, it can also have measurable consequences (8).

The first step in determining the indicators and selecting variables to measure resilience is to form a conceptual framework and apply it to the theoretical foundations of the research (9). The selection of indicators in resilience studies should be based on two criteria: justification based on the existing literature on its relevance to flexibility and availability as well as qualitative data from sources (10).

A study conducted by Cutter entitled a placebased model for understanding community resilience to natural disasters mentioned scalable indicators of infrastructure dimension of resilience, including the life of critical infrastructure, houses, commercial and manufacturing enterprises, along with the different dimensions of resilience. Moreover, the infrastructure dimension is considered to include the physical indicators of systems, such as the number of pipelines, road networks, which have external and internal connections to other infrastructures. The greater interconnectedness of these infrastructures leads to the reduction of resilience $(11,12)$.

A study entitled Resilience of Urban Planning: Major Principles and Criteria, reviewed nearly 43 out of the 332 articles, considering the evolution of the urban resilience concept.

Eventually, it was concluded that the indicators and criteria are combined according to a specific framework and none of them will act separately; therefore, their resilience should be examined in form of interrelationships and according to the relative quantity of each measurement (13). An article entitled Identification of Vulnerable Urban Fabric in Seismic Areas of Tehran examined the vulnerability of Tehran in three major parts, including buildings, worn-out urban fabric, vital sectors, along with search and rescue facilities, emergency medical and health facilities, temporary accommodation facilities, and emergency routes.

Based on the results, the priorities of urban fabric improvement cannot be reliably assessed if the impacts of earthquake-related indicators are ignored (14). The study conducted on the measurement and evaluation of the physical resilience of urban communities against earthquakes in Tehran's neighboring areas, different parameters have been considered, which include the number of main arteries, pipelines, roads, and critical infrastructure, transportation network, land use, shelter capacity, house type, material, building resilience, quality and age of building, ownership, type of construction, the height of buildings, outdoor space of the residential building, green areas, environmental density, access, geographical features (geotechnical features and slope), and the severity and recurrence of hazards and faults. The results showed that the neighboring regions of Tehran have different levels of physical resilience (15).

Another study entitled Study of the parameters of the vulnerability of urban fabrics to earthquakes in Tehran has evaluated such parameters as the vulnerability of buildings, road network, land hazards, location, industrial hazards, emergency response facilities, emergency accommodation along with the examination of the parameters of the world standard according to the local conditions of Tehran. Such parameters as population density, rate of poor population, the vulnerability of lines, especially water supply network, the ratio of free space around the buildings, as well as the social and economic conditions of the residents were considered important, however, these have not been considered in this study due to the lack of necessary evidence and documents.

Another study entitled assessing the physical resilience of a city against possible earthquakes assessed the physical resilience of district one of 
Tehran municipality against earthquakes by (16), ten indicators were used which included building materials, building age, building quality, number of building floors, ground floor area of buildings, compatibility of land uses, the width of roads, distance from unstable lands in terms of urban planning, the material of geological formations and distance from the fault. It was concluded that the city of Tehran has a low resistance to earthquakes due to its geographical and tectonic location, numerous active faults, the application of non-resistant materials, low-width roads, and unprincipled growth of the city near faults and unstable lands (10).

Parameters, such as main arteries, pipelines, roads, and vital infrastructure, transportation network, land use, shelter capacity, type of housing, material, building strength, building quality and age, ownership, type of construction, the height of buildings, open space of the residential building, green space, density of built environment, access, geographical features (geotechnical characteristics, slope), intensity and recurrence of hazards, faults, proximity to hazardous areas were considered as physical environmental indicators in a study entitled Explaining and analyzing the concept of resilience and its indicators and frameworks in natural disasters. Moreover, the most important feature in determining indicators of resilience was studied considering three approaches of sustainability, recovery, and transformation, and its comprehensive study was considered important (17).

Topographic maps, dispersion of faults in the region, municipal land-use map, population density, and altitude data were used in investigating the potential of earthquake-caused damage in Tehran district one. Furthermore, with regard to the tectonic conditions of Tehran district 1, such criteria as curvature coefficient, alluvial type, ground height, drainage density, relative fault density, population density, and percentage of open areas were considered as natural and human indicators that indicate seismicity. Moreover, the degradation potential caused by seismicity of the region was considered in five classes as well (18).

Characteristics such as slope, hypsometry, distance from the fault, distance from river, lithology, land use, and slope direction were considered important in the study of geomorphological straits and their impact on the physical development of the city of Givi was prioritized in another study. Furthermore, the role of planners and officials was considered significant in prohibiting construction in high-risk areas in this study (19).

The role of human aggression was investigated in the surrounding areas of this river with regard to the geometric parameters of the river in different time periods in a study entitled Hydrodynamics and stability of the Gheshlagh River and its effect on urban development in Sanandaj. It was concluded that the pattern of environmental changes resulting from human activities in the studied area has led to high human damages (20). Another study evaluated the interaction between geomorphological conditions and urban development of Kermanshah and changes in geomorphological features of the region caused by urban development activities. The identification of urban development was identified using topographic maps and satellite images. Eventually, the interactions of geomorphology and urban development were considered very important in the city of Kermanshah (21).

In another study, the physical resilience of Karaj city against earthquakes was studied according to the indicators of building, infrastructure, land use, fabric, urban structure, and natural factors. The physical resilience map of Karaj city was prepared at low, medium, and high levels. It was concluded that the most nonresilience is related to the central areas of the city (22).

In a study entitled Modeling of physical-social resilience of Tehran district 1 , the resilience zoning map of this area was prepared. Eventually, it was decided that districts $6,5,2$, and 3 had the least resilience and that more than half of the region was non-resilient (23).

Eventually, in a study entitled Measuring the resilience of Semnan city in the face of earthquakes, the resilience of Semnan city was studied considering four general indicators of socio-cultural, economic, physical infrastructure, and organizational institutional. The results of this study showed that the resilience of this city was desirable. Understanding the stability thresholds of a system is important for controlling the changes (24). The ability to predict sudden changes in the environment and the optimal use of resources and techniques are essential (25). 
Tehran is at high risk of earthquakes (26). This city has expanded in direction of active faults and unstable slopes in the last hundred years.

Given the dearth of performed studies on the correct understanding of the factors affecting urban resilience, this study seeks a concept of natural-disaster resilience, which establishes a link between vulnerability and resilience and be theoretically measurable. The aim was to investigate geographical landscape, with the emphasis on the natural perspective, as a platform for the formation of human societies, natural and human factors in interactions with each other in view of environmental physical resilience, and also measure the environmental physical indicators impacting urban resilience. The results can be used to solve problems in real places.

The main focus of this approach is on the resilience of places and human environments with specific natural characteristics and cities, as dense places of human habitation, are formed on the natural beds. The previous conditions (including vulnerability and resilience) are the starting point of this approach that is the product of processes of social systems, nature, and the environment. This concept acts as a triangle that shows how inherent processes occur at the local scale and leads to internal factors at the local level. It also includes external factors on a larger scale.

External factors affect internal factors, although their impact may not be directly measured. Contrary to some conceptualizations that oppose resilience and vulnerability, it is suggested to use the overlap of these concepts that can neither be examined separately nor mutually. There are many characteristics that affect only the vulnerability or the resilience of society. This study aimed to address the physical environmental dimensions of the city from the perspective of spatial resilience in order to respond to the impacts of immediate events in a special way resulting from the natural and human conditions of that space or place.

Therefore, this study aimed to measure resilience against natural hazards (earthquakes and floods) through the examination of the physical and environmental elements of Tehran city and their association with environmental factors and indicators in view of the natural perspective of the city.

Moreover, regarding the perspective of Tehran city and the characteristics of its physical bed, the physical environmental indicators have been studied in terms of urban resilience. Subsequently, this study assesses factors impacting the reduction or increase of vulnerability in the context of the physical perspective of the city, taking into account the studied indicators in previous studies given the physical environmental dimension of the urban perspective and international standards such as Hyogo Framework (27), Sendai Framework (28), and high-level documents, such as the Tehran Master Plan (29), as well as the third five-year urban development plan of Tehran city (30). Eventually, zoning maps of environmental physical resilience in Tehran were assessed after the determination of effective thresholds.

The studied area of the city of Tehran is located at 51 degrees and 6 minutes to 51 degrees and 38 minutes east longitude and 35 degrees and 34 minutes to 35 degrees and 51 minutes north latitude. Tehran's height above sea level varies and is $1800 \mathrm{~m}$ in the north, $1200 \mathrm{~m}$ in the center, and $1050 \mathrm{~m}$ in the south. This city is located in a relatively flat plain between the Alborz Mountains and the northern edge of the central desert of Iran. This relatively flat plain is extended to the mountains of Rey and Bibi Shahrbanoo, and the plains of Shahriyar and Varamin from the south and southwest and is surrounded by mountains in the north. East It turns out that they join near the salt desert in the southeast of Tehran. The geographical space of Tehran is determined by the two rivers of Karaj in the west and Jajroud in the east in the mountains and plains, which join near the salt desert in the southeast of Tehran.

The knowledge of the spatial distribution of landforms is the focus of studies in applied geomorphology in order to understand and evaluate their evolution and stability (31). Landforms constituting the urban regions are divided into several categories: natural physical landforms, man-made artificial landforms, and artificial physical landforms that have been modified to form the bed of facilities and infrastructure and are destroyed in some cases. There are differences in the intensity and weakness of changes on landforms in different parts of the city. The city expansion and constructions led to the destruction of landforms and rapid changes, flattening and elimination of 
steep slopes, deformation of the basin, redirection of waterways, and subsequent imbalance of the drainage system. All of these lead to such phenomena as landslides, falls, subsidence, floods as well as urban hazards (32).

\section{Methods}

This is an applied descriptive-analytical study. The data and maps used for digital layers used in the study are taken from the Tehran Municipality Information and Communication Technology and the Geological Survey and Mineral Exploration of Iran, as well as the International Earthquake Research Institute of Tehran.

Four steps were used for investigating the relationship between the natural perspective of Tehran based on form and geomorphological processes and the study of earthquake and flood hazards as the most important phenomenon in measuring the resilience of Tehran which included data collection (satellite images, digital elevation model (DEM), geological and topographic layers and aerial photographs for preparation of a geomorphological map of Tehran), data processing, calculation of indicators, and analysis of findings.

Basic data, including satellite images, such as Landsat TM and DEM provide a systematic view of the elements and along with field observations made up the perspective of Tehran city. Subsequently, the role of geomorphic form and processes and the effective indicators on the environmental physical structure of Tehran city were extracted. Furthermore, equilibrium models and geomorphic thresholds governing the perspective of Tehran were investigated in the relationship between form and process and the physical structure of Tehran. Eventually, the resilience level of Tehran city was examined.

In this study, effective indicators for determining the thresholds of environmental physical dimensions were assessed based on domestic and foreign studies, as well as high-level documents, such as frameworks of Hyogo, Sendai, Tehran master plan, and the third fiveyear plan of Tehran Municipality in order to determine the resilience thresholds of Tehran city.

For the aim of obtaining thresholds of resilience through the conceptual approach of the study and the amount of data available, such as population and building density, transportation network, distance from and proximity to industries, as well as urban land uses, the worn fabric was selected and prioritization of indicators and their classification was conducted regarding the contribution of each factor in the resilience level. In the next stage, the zoning map of Tehran's resilience was prepared. Eventually, the existing spatial resilience of Tehran city was analyzed to determine the necessary strategies for the reduction of vulnerability and damage.

The studied area was divided into three natural urban perspectives of north, center, and south with the aim of determining thresholds of urban resilience regarding the characteristics of topography, physiography, geology, the results of field studies, satellite images, aerial photographs as well as the study of paleogeomorphological research in Tehran. The perspective of Tehran's northern mountains starts from the northern part of Tehran at an altitude of $1800 \mathrm{~m}$ and ends at $1500 \mathrm{~min}$ in its southern direction.

The existence of active faults in the north of Tehran is one feature of this perspective. This perspective is spread over the southern slopes of the Alborz Mountains. Among the obvious geomorphological features of this perspective, one can refer to are the existence of conglomerate hills that play an important role in creating differences in height and surface unevenness of this perspective that leads to the hills and valleys of Evin, Darakeh, Niavaran, Hesarak, and Sohanak and always attracts a large number of people.

The second natural perspective is called the central perspective, which extends from an average altitude of $1,500 \mathrm{~m}$ north to $1,100 \mathrm{~m}$, which is related to the geomorphological forms of old and new alluvial fans. The natural perspective of the south of Tehran is expanded from a height of $110 \mathrm{~m}$ to a height of $1035 \mathrm{~m}$. This perspective corresponds with fine-grained sediments and alluvial plains.

Finally, the resilience threshold of each dimension was determined in the framework of the triple perspectives to explain and analyze the existential philosophy of this difference in the issue of resilience and provide effective strategies for each perspective in order to reduce the vulnerability and increase urban resilience (Figure $1)$.

In order to prepare a resilience map of Tehran city perspectives based on the given indicators, the score of each sub-index in the information table of the layers according to the high-level 
documents, previous researches, and expert opinion, all layers were prioritized and each one was scored based on fuzzy value and applied in two levels of existence

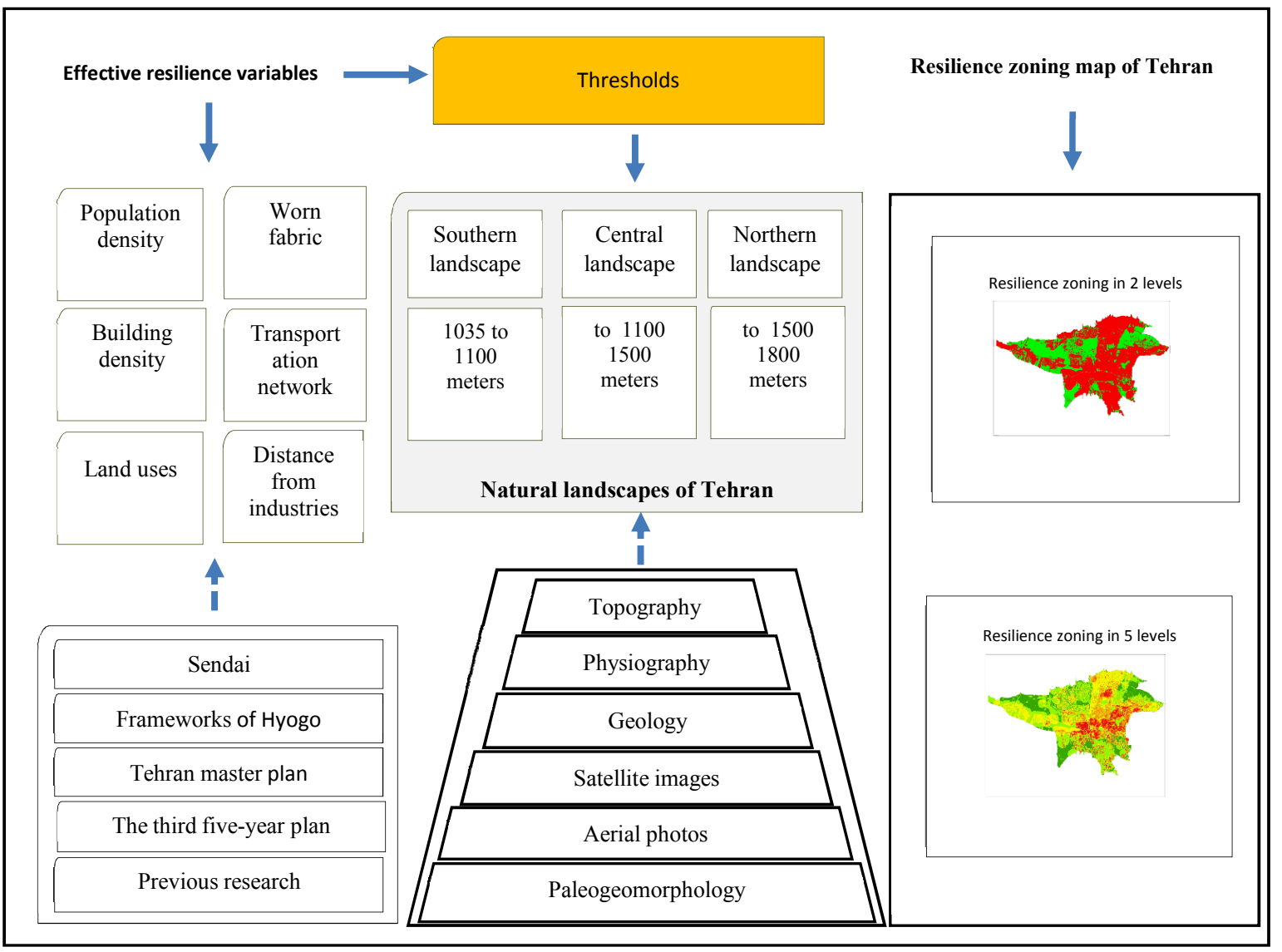

Figure 1. Infographic of the process of preparing resilience maps of Tehran

and absence of fluency in the framework of conditional functions in GIS environment considering Boolean logic. In the next stage, the layers of each indicator were integrated with each other according to the processes performed separately for the two hazardous phenomena of Tehran (earthquake and flood), and at the same time the resilience of each of the northern natural perspectives. Central and southern-based on two phenomena of urban floods and earthquakes were prepared as a zoning map.

Conditional functions can evaluate the output value of each cell (pixels of raster layers), according to the actual value in a given conditional expression. Conceptually, during the execution, the conditional functions from each cell location determine whether the cell is true (1) or false (0) based on the performed evaluations, cell value, and the conditional expression. If the cell is evaluated as correct, the output value for that location is specified in the actual input, and if the cell is evaluated as incorrect, the output value for that location is specified in the false input.

In a GIS environment, there are two ways to identify the correct or incorrect location of a cell: 1) through an input raster layer, 2) by an input raster layer in which an optional input expression is applied. In the present study, the first method has been used through Spatial Analyst.

The input of multiple rasters is possible when the conditional tool is evaluated for each $\mathrm{x}$ and $\mathrm{y}$ cell before moving to the next cell. When multiple rasters are entered, the specified operator or tool is processed cell-by-cell between several rows.

Therefore, if a value of 10 (marked as a fixed constant) and 1 (marked as a false constant) are considered suitable and unsuitable for construction, respectively, based on a slope in a cell (specified by the input conditional), and a slope of below $15 \%$ is considered good, the phrase "value $<15$ " should be entered. If a cell has a slope of below $15 \%$, it receives the true value (10 in this case). Otherwise, it receives a 
value that is specified as incorrect (in this case 10) (33).

\section{OutRas=Con (SlopeRas, 10, 1, "VALUE < 15")}

Therefore, in this study, the conditional tool in Arc Map was employed in order to place the selected layers on top of each other. Based on the following equation, the combination of indicators was used to prepare the final map of each defined perspective, based on earthquake and flood phenomena, in two levels of the Tehran city as three perspectives and one perspective.

The perspective of the whole city of Tehran based on the earthquake phenomenon:

OutRas=Con( $\mathrm{x} 1$, "VALUE $\leq 1 "+\mathrm{x} 2$,"VALUE $\leq$ $10 "+x 3$, "VALUE $\leq 100 "+x 4$, "VALUE $\leq 100 "+$ $\mathrm{x} 5$,"VALUE $\leq 10000 " \mathrm{x} 6$, ,VALUE $\leq 100000 "$ )

Perspective of the whole city of Tehran based on the flood phenomenon:

OutRas=Con $(x 4$, "VALUE $\leq 1 "+\mathrm{x} 1$,"VALUE $\leq$ $10 "+$ x2, "VALUE $\leq 100 "+$ x3, "VALUE $\leq 100 "+$ x5,"VALUE $\leq 10000 " x 6, " V A L U E \leq 100000 ")$

Perspective of North of Tehran based on earthquake phenomenon:

OutRas=Con $(x 1$, "VALUE $\leq 1 "+\mathrm{x} 2$, ,VALUE $\leq$ $10 "+\mathrm{x} 3$, "VALUE $\leq 100 "+\mathrm{x} 5$, "VALUE $\leq 100 "+$ $\mathrm{x} 4$,"VALUE $\leq 10000 " \mathrm{x} 6$, ,VALUE $\leq 100000 "$ )

Perspective of the center of Tehran based on the earthquake phenomenon:

OutRas=Con( $\mathrm{x} 1$, "VALUE $\leq 1 "+\mathrm{x} 2$,"VALUE $\leq$ $10 "+\mathrm{x} 3$, "VALUE $\leq 100 "+\mathrm{x} 5$, "VALUE $\leq 100 "+$ $\mathrm{x} 4$, ,VALUE $\leq 10000$ "x6,"VALUE $\leq 100000 "$ )

South of Tehran perspective based on the earthquake phenomenon:

OutRas=Con $(x 3$, "VALUE $\leq 1 "+$ x2,"VALUE $\leq$ $10 "+\mathrm{x} 1$, "VALUE $\leq 100 "+\mathrm{x} 5$, "VALUE $\leq 100 "+$ $\mathrm{x} 4$,"VALUE $\leq 10000 " \mathrm{x} 6$, ,VALUE $\leq 100000 "$ ")

North of Tehran perspective based on flood phenomenon:

OutRas $=$ Con $(\mathrm{x} 4$, "VALUE $\leq 1 "+\mathrm{x} 1$,"VALUE $\leq$ $10 "+\mathrm{x} 2$, "VALUE $\leq 100 "+\mathrm{x} 5$, "VALUE $\leq 100 "+$ $\mathrm{x} 4$, ,VALUE $\leq 10000$ "x6,"VALUE $\leq 100000 "$ )

Perspective of the center of Tehran based on the flood phenomenon:
OutRas=Conx4(, "VALUE $\leq 1 "+\mathrm{x} 1$, "VALUE $\leq$ $10 "+\mathrm{x} 3$, "VALUE $\leq 100 "+\mathrm{x} 5$, "VALUE $\leq 100 "+$ $\mathrm{x} 2$, ,VALUE $\leq 10000$ "x6,"VALUE $\leq 100000 "$ ")

South of Tehran perspective based on flood phenomenon:

OutRas=Conx4 $($ "VALUE $\leq 1 "+\mathrm{x} 1$,"VALUE $\leq$ $10 "+\mathrm{x} 3$, "VALUE $\leq 100 "+\mathrm{x} 2$, "VALUE $\leq 100 "+$ $\mathrm{x} 5$,"VALUE $\leq 10000 " \mathrm{x} 6$, ,VALUE $\leq 100000 "$ )

Con $=$ Conditional

$\mathrm{X} 1=$ Building density

$\mathrm{X} 2=$ Population density

$\mathrm{X} 3=$ Decayed fabric

$\mathrm{X} 4=$ Transportation

$\mathrm{X} 5=$ Land use

$\mathrm{X} 6=$ Distance from industries

\section{Findings}

According to the theoretical approach of the study on natural perspective theory, the city of Tehran was divided into three natural perspectives: Northern, Central, and Southern perspectives (Figure 2).

\section{The northern natural perspective of Tehran}

Based on the approved boundaries of Tehran in the comprehensive plan of 2007, the borderline of the northern area of the city is determined at 1800 meters. There is a sensitivity of planning and executive measures in this area. This can be attributed to environmental processes prevailing in the northern area, such as high slope, significant height difference in the north-south area, the existence of an active fault line along the east-west, the average snowfall, and heavy rain, compared to other parts of the city, the settlement on the slopes of Alborz due to the weathering process and the difference of day and night temperatures during the year, high population attraction due to provide urban services in this area, ecological, geological, and geographical sensitivity due to the natural perspective of this perspective, as well as other characteristics. The north-south boundary of this perspective has been extended from $1800 \mathrm{~m}$ to $1500 \mathrm{~m}$ as a result of the prevailing processes and forms and social factors.

\section{Central natural perspective of Tehran}

The existence of conglomerate hills that have spread throughout the northern perspective along the west-east is one of the features of the 


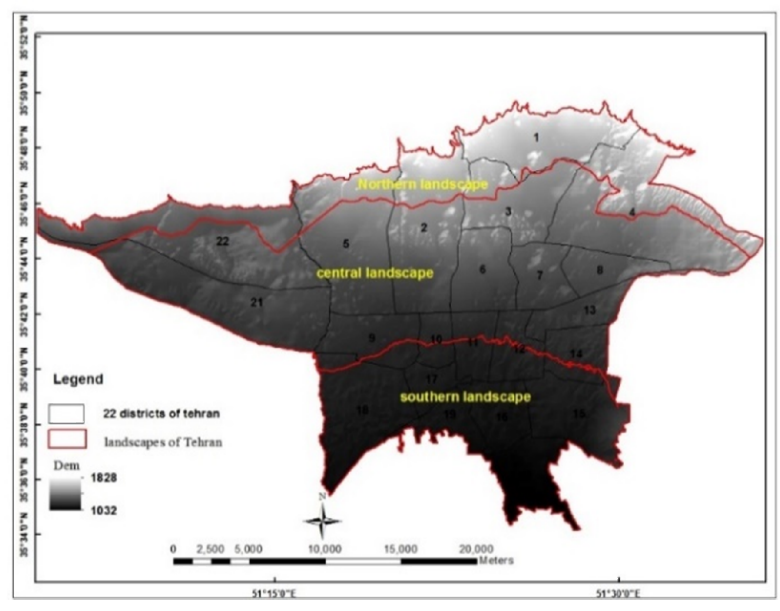

Figure 2. Natural perspective of Tehran in northern, central, and southern levels

central perspective of Tehran. The predominant features in the central perspective of Tehran city which has expanded in height from $1500 \mathrm{~m} 110 \mathrm{~m}$ include running waters, receiving a significant volume of the upstream flood, the use of this perspective as the west-east and north-south corridor of the city in the urban transportation network, high commercial and administrative land use in this area, the absence of empty and barren lands, the high density of building and population, the vast urban area, the existence of diverse social classes.

\section{South of Tehran natural perspective}

Existence of active faults, such as north-south Rey fault, accumulation of urban floods and running waters in this area, high abundance of worn and unstable urban fabrics, especially in areas populated with lower social classes, impermeability of urban fabrics, lack of services and facilities, especially for the management of crisis are among the features of this area, which is expanded from a height of $110 \mathrm{~m}$ to $1035 \mathrm{~m}$ due to the predominant formation processes and paleoclimatology factors, such as water and ice distribution line.

Following the determination of the natural perspective of the city of Tehran into three different perspective with differences and similarities to each other, the desired indicators were determined according to the presence and absence of resilience in order to determine the threshold of each perspective based on the conducted studies on urban resilience of Tehran city, the characteristics of the natural perspective of Tehran, as well as experts' opinion (Table 1).

In order to compare the natural perspective of Tehran city from the perspective of two phenomena of earthquake and flood, the resilience zoning map of Tehran was obtained in form of a perspective with regard to five levels of resilience from very low to very high (Figures 3 and 4).

Subsequently, zoning maps of the resilience perspective of Tehran were prepared in three different perspectives with respect to the existence or lack of resilience (Figures 5 and 6).

According to the seismic zoning map, the western half of Tehran has the highest resilience. The southwestern and northeastern parts are the most resilient, while the central districts of the city, including districts $3,6,7,8,9,10,11,12,13$, and 14 have the most non-resilience. Moreover, the non-resilient areas and points are scattered throughout the city and are mostly distributed in the southern half of the city.

Table 2 and Figure 4 present the percentage of resilience in Tehran city in view of the earthquake phenomenon. In general, it can be said that according to the zoning map of Tehran city from the perspective of the earthquake (Figure 3), which results from the zoning of the city in one perspective and based on five levels, the highest distribution and frequency of non-resilience is related to the central areas of the city.

Table 1. Characteristics of resilience parameters at different levels of the Tehran city perspective

\begin{tabular}{|c|c|c|c|c|c|c|}
\cline { 1 - 4 } Perspective & $\begin{array}{c}\text { Building } \\
\text { density }\end{array}$ & $\begin{array}{c}\text { Population } \\
\text { density }\end{array}$ & $\begin{array}{c}\text { Urban } \\
\text { Decayed } \\
\text { Fabric }\end{array}$ & Land use & $\begin{array}{c}\text { Distance } \\
\text { from } \\
\text { industries }\end{array}$ & Street width \\
\hline $\begin{array}{c}\text { North Tehran } \\
\text { perspective } \\
\text { (earthquake) }\end{array}$ & $100-0 \mathrm{~m}$ & $250-0$ & $\begin{array}{c}\text { Not } \\
\text { decayed }\end{array}$ & $\begin{array}{c}\text { Agricultural } \\
\text { green space } \\
\text { Military } \\
\text { Other } \\
\text { Wasteland }\end{array}$ & Over $1000 \mathrm{~m}$ & Over $30 \mathrm{~m}$ \\
\hline
\end{tabular}




\section{Table 1. Continued}

\begin{tabular}{|c|c|c|c|c|c|c|}
\hline $\begin{array}{l}\text { North Tehran } \\
\text { perspective } \\
\text { (flood) }\end{array}$ & $60-0$ & $250-0$ & $\begin{array}{c}\text { Not } \\
\text { decayed }\end{array}$ & $\begin{array}{c}\text { Agricultural } \\
\text { green space } \\
\text { Military } \\
\text { Other Wasteland }\end{array}$ & Over $1000 \mathrm{~m}$ & $\begin{array}{l}\text { connection with the } \\
\text { street width } \\
\text { Direct correlation with } \\
\text { street density in a } \\
\text { given space }\end{array}$ \\
\hline $\begin{array}{l}\text { Perspective of } \\
\text { central Tehran } \\
\text { (earthquake) }\end{array}$ & $100-0 \mathrm{~m}$ & $250-0$ & $\begin{array}{c}\text { Not } \\
\text { decayed }\end{array}$ & $\begin{array}{c}\text { Military } \\
\text { wasteland } \\
\text { green space } \\
\text { agricultural } \\
\text { other services } \\
\text { warehouse }\end{array}$ & Over $1000 \mathrm{~m}$ & Over $1000 \mathrm{~m}$ \\
\hline $\begin{array}{l}\text { The perspective } \\
\text { of the center of } \\
\text { Tehran (flood) }\end{array}$ & $60-0$ & $250-0$ & $\begin{array}{c}\text { Not } \\
\text { decayed }\end{array}$ & $\begin{array}{c}\text { Military } \\
\text { Other wasteland } \\
\text { agricultural } \\
\text { services } \\
\text { warehouse }\end{array}$ & Over $1000 \mathrm{~m}$ & $\begin{array}{l}\text { Lack of direct } \\
\text { connection with the } \\
\text { street width } \\
\text { Direct correlation with } \\
\text { street density in a } \\
\text { given space }\end{array}$ \\
\hline $\begin{array}{l}\text { South Tehran } \\
\text { perspective } \\
\text { (earthquake) }\end{array}$ & $60-0$ & $250-0$ & $\begin{array}{c}\text { Not } \\
\text { decayed }\end{array}$ & $\begin{array}{c}\text { Other } \\
\text { Wasteland } \\
\text { Agricultural }\end{array}$ & Over $1000 \mathrm{~m}$ & $\begin{array}{c}\text { Above } 45 \text { and streets } \\
\text { that connect to streets } \\
\text { with a width of } 45 \\
\text { meters. }\end{array}$ \\
\hline $\begin{array}{l}\text { South Tehran } \\
\text { perspective } \\
\text { (flood) }\end{array}$ & $60-0$ & $250-0$ & $\begin{array}{c}\text { Not } \\
\text { decayed }\end{array}$ & $\begin{array}{c}\text { Other } \\
\text { Wasteland } \\
\text { Agricultural } \\
\text { Green space }\end{array}$ & Over $1000 \mathrm{~m}$ & $\begin{array}{l}\text { Lack of direct } \\
\text { connection with the } \\
\text { street width } \\
\text { Direct correlation with } \\
\text { street density in a given } \\
\text { space } \\
\text { Direct connection with } \\
\text { the direction of the } \\
\text { streets due to drainage }\end{array}$ \\
\hline
\end{tabular}

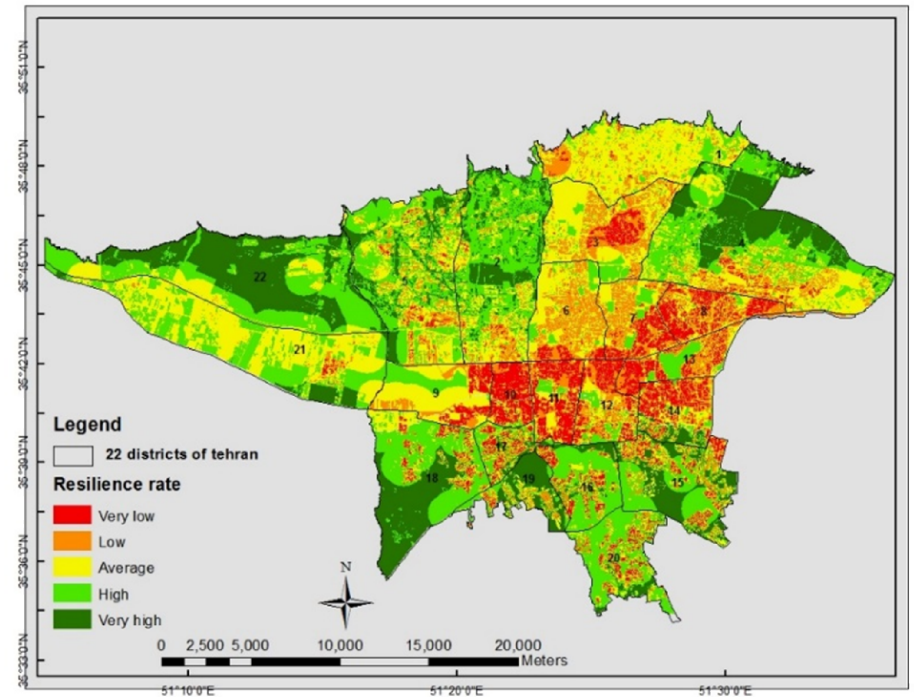

Figure 3. Zoning map of the resilience of Tehran city from the perspective of the earthquake in five levels according to one perspective 


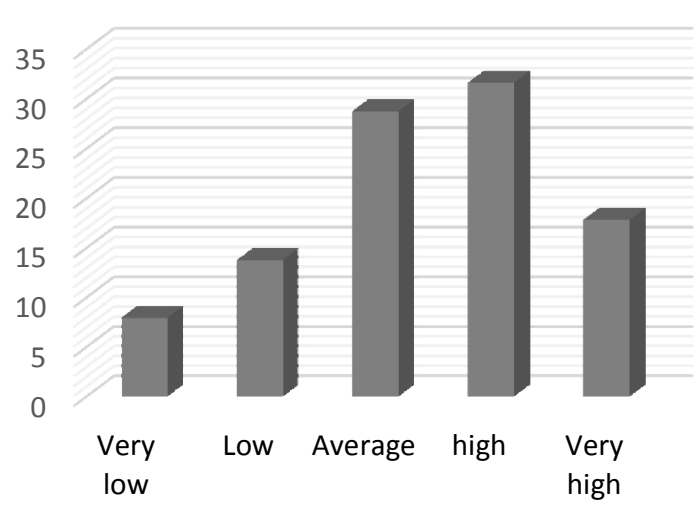

Figure 4. Resilience diagram of Tehran based on earthquake phenomenon

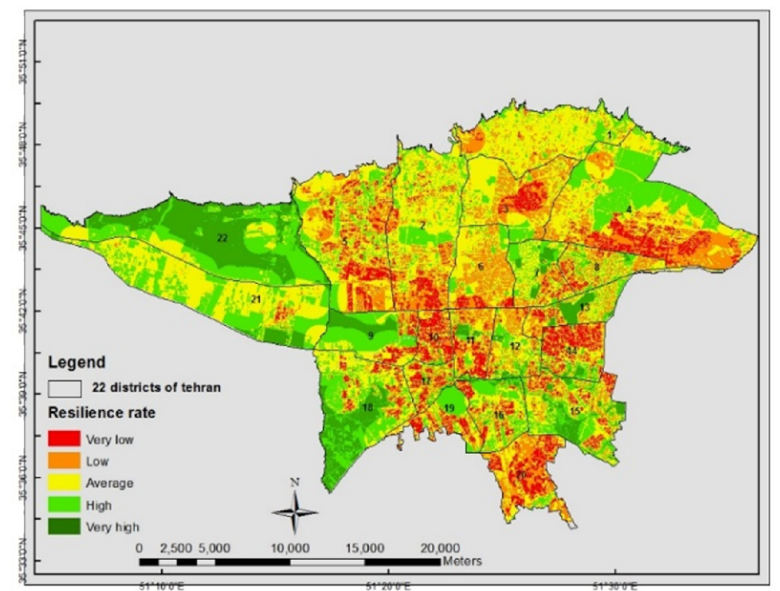

Figure 5. Resilience zoning map of Tehran from the perspective of flood in five levels according to one perspective

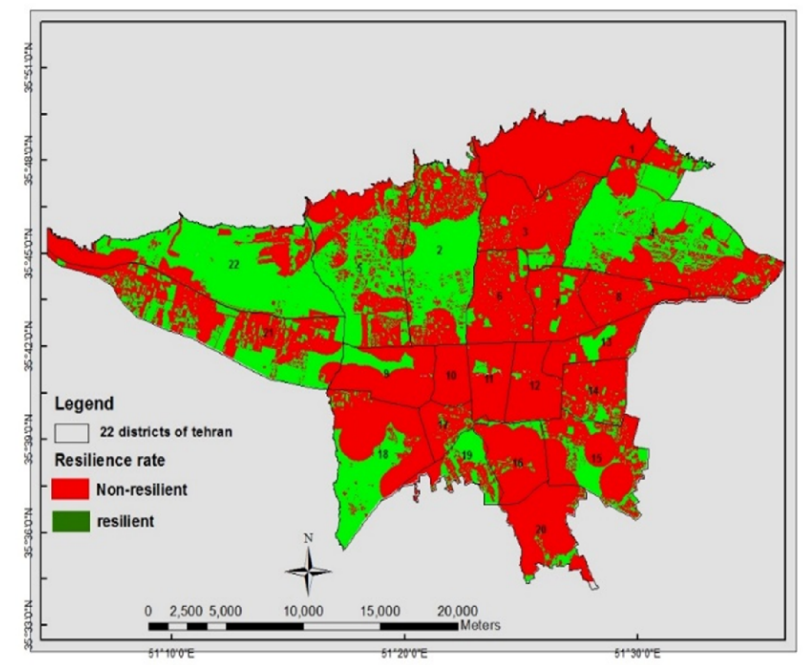

Figure 6. Resilience diagram of Tehran city based on flood phenomenon
According to the flood zoning map, the highest resilience is related to the northwest and southwest, which constitutes about $10 \%$ of the total area (Table 3 and Figure 6). The next resilient areas are located in the northeastern regions and to some extent the western half of Tehran. The most non-resilient areas are located in the central areas of the city which covers the central half of the city with a north-south extension. The distribution of non-resilience in the central areas has reached a higher density and frequency and reaches the highest nonresilience in the southernmost part of the city (corresponding to district 20 of Tehran city) with a discontinuous distance.

In general, it can be said that based on Figures 5 and 6 obtained from the zoning map of floods in Tehran in one perspective and based on five levels, the highest distribution and frequency of non-resilience is located in the central, eastern, and southern regions of the city.

Based on the zoning of Tehran city in terms of earthquake phenomenon and the division of Tehran into Northern, Central, and Southern perspectives (Figure7), the highest distribution of non-resilience and density is located in the northern regions of the city (Region 1, 3, 6 and the northern areas, districts $2,5,22$ ) with eastwest extension and southern areas of the city (15, $16,17,20$ and the main parts of area 18). This non-resilience is also evident in the central areas of the city in a concentrated way. Northeastern regions (district4), southwestern regions (parts of district 18), and the western half inclined to the south (southern districts 2, 5, 22) have the highest urban resilience to the earthquake (Table 4 and Figure 8).

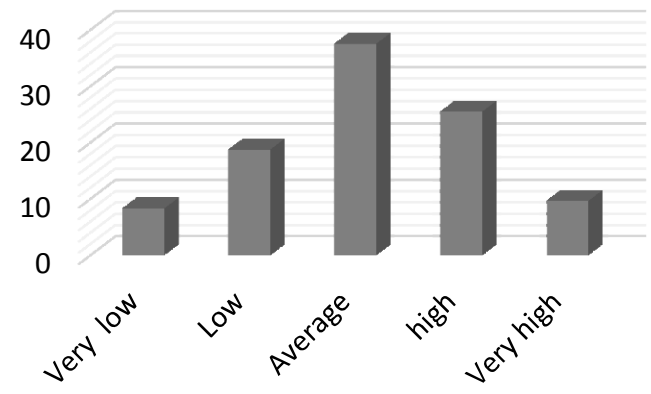

Figure 7. Resilience zoning map of Tehran city from the perspective of the earthquake in two levels according to three perspectives 
Table 2. Resilience rate of Tehran in terms of earthquake phenomenon

\begin{tabular}{cccc}
\hline Row & Resilience rate & Area $\left(\mathbf{M}^{\mathbf{2}}\right)$ & Percentage \\
\hline 1 & Very low & $47,580,000$ & $7 / 95$ \\
2 & Low & $82,505,000$ & $13 / 78$ \\
3 & Average & $172,230,000$ & $28 / 77$ \\
4 & High & $189,395,000$ & $31 / 64$ \\
5 & Very high & $106,865,000$ & $17 / 85$ \\
\hline
\end{tabular}

Table 3. Resilience of Tehran city in terms of flood phenomenon

\begin{tabular}{cccc} 
Row & $\begin{array}{c}\text { Resilience } \\
\text { rate }\end{array}$ & Area $\left(\mathbf{M}^{2)}\right.$ & Percentage \\
\hline 1 & Very low & $50,017,500$ & $8 / 36$ \\
2 & Low & $112,545,000$ & $18 / 8$ \\
3 & Average & $225,030,000$ & $37 / 59$ \\
4 & High & $152,950,000$ & $25 / 55$ \\
5 & Very high & $58,030,000$ & $9 / 69$ \\
\hline
\end{tabular}

Based on the zoning of Tehran city with respect to flood phenomenon and the division of Tehran perspective into northern, central, and southern perspective (Figure 9), the highest distribution and density of non-resilience is located in the northern regions of the city (District1, 2, 3, 5, 6, 20 and major parts of the district $21,14,17,22$ ). This non-resilience is also scattered in the central areas of the city. Northeast (district 4), southwest (part of district 18), and district 22 of Tehran have the highest urban resilience with respect to floods (Table 5 and Figure 10).

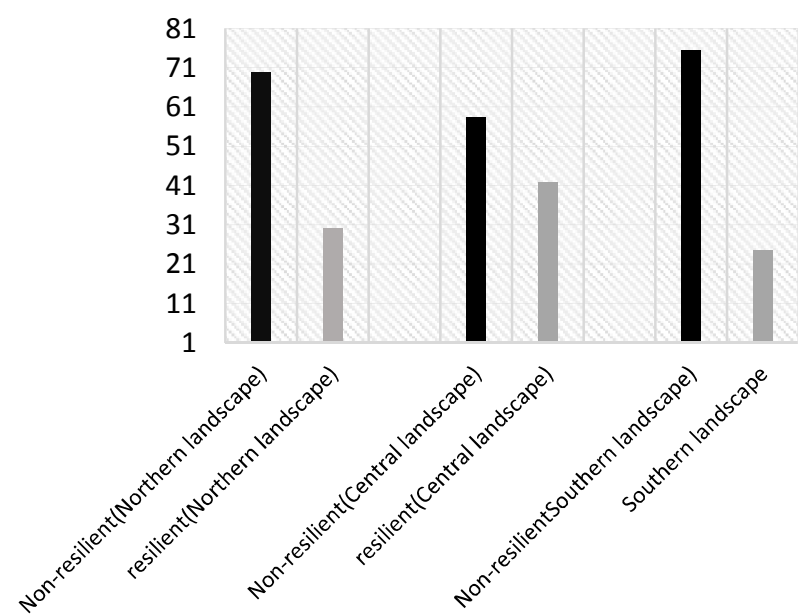

Figure 8. Resilience diagram of Tehran based on earthquake phenomenon

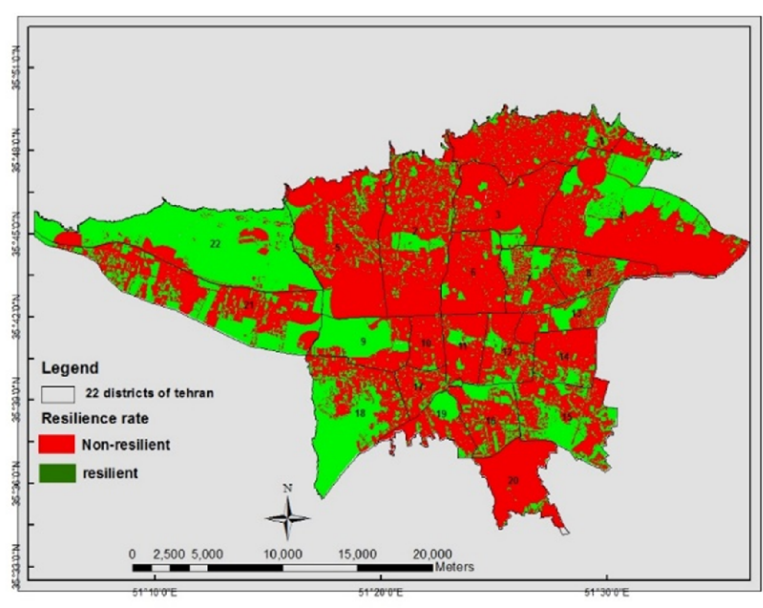

Figure 9. Resilience zoning map of Tehran city from the perspective of flood in two levels according to three perspectives

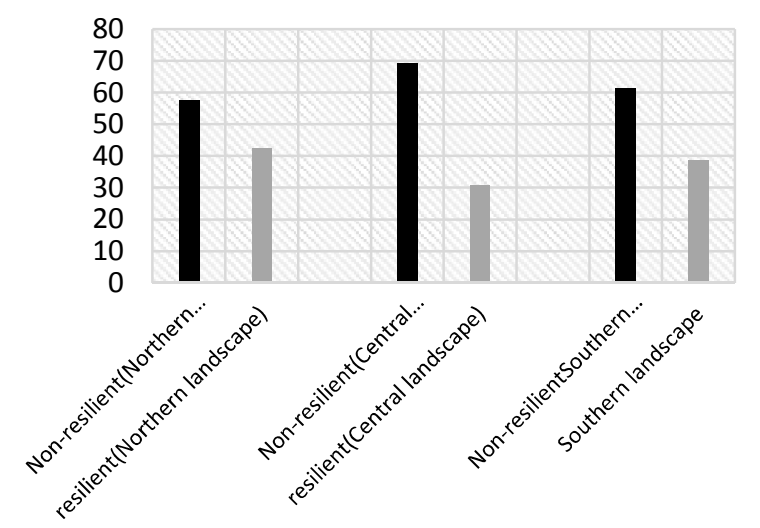

Figure 10. Resilience diagram of Tehran city based on flood phenomenon

Table 4. Resilience rate of Tehran city in terms of earthquake phenomenon

\begin{tabular}{c|ccc} 
Perspective & $\begin{array}{c}\text { Resilience } \\
\text { Level (two } \\
\text { levels) }\end{array}$ & $\mathbf{M}^{2}$ & \multirow{2}{*}{ Percentage } \\
\cline { 1 - 2 } $\begin{array}{c}\text { North Tehran } \\
\text { perspective }\end{array}$ & $\begin{array}{c}\text { Non- } \\
\text { resilient } \\
\text { Resilient }\end{array}$ & $91,452,500$ & $69 / 92$ \\
& $39,340,000$ & $30 / 08$ \\
$\begin{array}{c}\text { Central } \\
\text { Tehran } \\
\text { perspective }\end{array}$ & $\begin{array}{c}\text { Non- } \\
\text { resilient } \\
\text { Resilient }\end{array}$ & $189,540,000$ & $58 / 29$ \\
& $\begin{array}{c}\text { Non- } \\
\text { resilient }\end{array}$ & $108,375,000$ & $75 / 53$ \\
$\begin{array}{c}\text { South Tehran } \\
\text { perspective }\end{array}$ & Resilient & $35,112,500$ & $24 / 47$ \\
\hline
\end{tabular}


Table 5. Resilience of Tehran city based on flood phenomenon

\begin{tabular}{c|ccc}
\hline Landscape & $\begin{array}{c}\text { Resilience } \\
\text { rate (two } \\
\text { levels) }\end{array}$ & Area $\left(\mathbf{M}^{2}\right)$ & Percentage \\
\hline $\begin{array}{c}\text { North } \\
\text { Tehran } \\
\text { perspective }\end{array}$ & $\begin{array}{c}\text { Non- } \\
\text { resilient }\end{array}$ & $75,390,000$ & $57 / 64$ \\
& Resilience & $55,402,500$ & $42 / 36$ \\
$\begin{array}{c}\text { Central } \\
\text { Tehran }\end{array}$ & $\begin{array}{c}\text { Non- } \\
\text { resilient }\end{array}$ & $224,812,500$ & $69 / 13$ \\
perspective & Resilient & $100,375,000$ & $30 / 87$ \\
$\begin{array}{c}\text { South } \\
\text { Tehran }\end{array}$ & $\begin{array}{c}\text { Non- } \\
\text { resilient }\end{array}$ & $87,920,000$ & $61 / 27$ \\
perspective & Resilient & $5,556,5000$ & $38 / 73$ \\
\hline
\end{tabular}

\section{Discussion and Conclusion}

In many cases, dynamic instability in many urban perspectives is responsible for many contradictory responses and inherent complexity, regarding the similarities and differences in relation to each other in the whole physical urban perspective. Therefore, reconsideration and redefinition of physical urban perspective are necessary, not in the form of one perspective but in the framework of different perspectives with different characteristics and responses.

In this research, based on zoning maps of urban flood and earthquake and considering the city of Tehran in terms of two different natural perspective approaches (the first approach considers the city of Tehran in one perspective and the next approach considers the city of Tehran according to the natural and human characteristics in northern, central, as well as southern perspectives), it is concluded that comprehensive risk management in Tehran should be done according to the natural and inherent nature of this city. The reason is that according to the thresholds of environmental physical resilience of Tehran metropolis, this city has three lands or perspectives that have different natural conditions and characteristics.

The highest resilience is related to the western half of Tehran city in terms of the earthquake phenomenon in one natural perspective. Moreover, small areas with low resilience thresholds are scattered throughout the city; however, based on three northern, central, and southern perspectives the highest distribution of non-resilience is located in the northern and the southern districts of the city. Furthermore, in the central areas of the city, this resilience is more obvious, compared to the ern and southern perspectives.

Regarding the flood risk in Tehran, according to a single natural perspective, the highest resilience can be observed in the northwest and southwest, and the highest non-resilience is observable in the central areas, which is increased toward the south of the city. However, according to the zoning of Tehran in three perspectives of north, center, and south, the most non-resilience is observable in the northern regions of the city. Furthermore, parts of the northeastern regions (district 4) and southwestern regions (parts of districts 18 and 22) have the highest urban resilience to floods.

The adaptation of the research findings with the studies conducted on the earthquake phenomenon in Tehran areas shows the importance of local vision and surveys of Tehran areas in a specific region (1). One of these studies is conducted on Tehran district 12, which indicates that the level of resilience in this region is low in the event of an earthquake (1). Another study has measured the urban resilience of district 1 of Tehran against the earthquake. It was revealed that this area is non-resilient, high sensitive, and vulnerable to earthquakes (2). The western regions of this area had less vulnerability, compared to the central and eastern regions which are due to the strength of buildings.

Based on the results of a study conducted on the hazards of earthquakes in district 20 of Tehran (3), it was indicated that this region is highly exposed to earthquake hazards and has low resilience. More than $50 \%$ sensitivity of district 10 of Tehran to earthquakes and its low resilience (4) are the results of studies conducted on the resilience of Tehran city to earthquakes. The comparison with resilience zoning maps of Tehran (Figures 3 and 7) indicates the compliance of the findings of the above studies with the approach of studying the resilience of Tehran from three different perspectives.

Regarding the correspondence between the research findings and the researches that have been performed on the flood in Tehran, one can refer to a study performed on the factors that affect the spatial variability of flood risk in the metropolis of Tehran (5). The obtained results showed that the risk of flood in Tehran does not 
have a fixed spatial distribution in relation to the natural bed of the city and the existing differences in the urban indices of Tehran.

In another study conducted on the resilience of the city of Tehran against floods, the Spatiotemporal changes of floods were considered important due to the inherent nature of the different atmosphere of Tehran (6). Comparison of the results of the above-mentioned studies on the resilience of Tehran city to floods with the findings of the present study (Figures 5 and 9) showed the spatial incompatibility of the flood in Tehran with its natural bed, which is due to the interruption of natural drainage areas in Tehran in urban development projects and the creation of artificial areas. The comparison of the findings of the above study with the zoning map of flood in Tehran city, considering northern, central, and southern perspectives it can be concluded that that the approach of considering different perspectives in the resilience of the city after the flood is consistent with the research findings.

This study aimed to determine the resilience of Tehran city for urban planning, with the emphasis on issues related to the morphology of urban space, which makes the appropriate assessment subject to the evaluation of indicators that result from the specifics feature of a given area and the identification of its changes over time. The studies in this field are insufficient (7), and urban resilience is dependent on the variables and indicators specific to that city. In general, the assessment of resilience should be conducted using hybrid methods with an emphasis on the inherent physical characteristics of the city and the behaviors resulting from the changes (8).

Based on the obtained results of this study which has been conducted according to the different inherent natural characteristics of the whole area of Tehran city, as the natural hazard bed of this city, it is indicated that having one natural perspective approach leads to an incomplete understanding of impactful variables in the natural perspective and bedrock of Tehran regarding the hazard perspective.

Planning in view of Tehran city in a single natural perspective is what has been considered in previous studies as well as operational plans for managing the resilience crisis of Tehran city in theory and practice. The operational plans and managerial measures taken in this city are indicative of the fact that in order to promote the resilience of Tehran city and manage the urban crisis, there is a need for an integrated physical view of all areas of Tehran city. However, the body of the city is located on a bed that has its own feedback during the earthquakes and floods in different natural perspectives, regarding the process of formation and evolution. Therefore, different policies, strategies, operational approaches, and actions are required in each perspective.

In other words, the type of destruction caused by a particular phenomenon in different perspectives of Tehran is not the same and different reactions can be observed. Accordingly, an event that is considered a hazard in one part of the city of Tehran is not considered dangerous in another perspective, with resilience resulting from its special inherent conditions. On the other hand, based on the studied perspectives, the approach of spatiotemporal changes of resilience in Tehran is useful in strengthening all levels of optimal management of the crisis in the city of Tehran.

\section{Acknowledgments}

None

\section{Conflict of Interests}

Authors have no conflict of interests.

\section{References}

1. Dadashpoor H, Adeli Z. Measuring the amount of regional resilience in Qazvin urban region. J Emerg Manag 2016; 4(2): 73-84 [In Persian].

2. Chen $\mathrm{C}, \mathrm{Xu}$ L, Zhao D, Xu T, Lei P. A new model for describing the urban resilience considering adaptability, resistance and recovery. Saf Sci 2020; 128: 104756.

3. Grafakos S, Gianoli A, Tsatsou A. Towards the development of an integrated sustainability and resilience benefits assessment framework of urban green growth interventions. Sustainability 2016; 8(5): 461.

4. Khorshiddoust AM, Rezaeimoghaddam M, Ahmadi $\mathrm{M}$, Khaleghi S. The role of river geomorphic processes in environmental hazards of Songhor in Kermanshah province. Geographic Space 2011; 35: 209-34 [In Persian].

5. Uday P, Marais KB. Resilience-based system importance measures for system-of-systems. Proc Comput Sci 2014; 28: 257-64.

6. Lundberg J, Johansson BJ. Systemic resilience model. Reliabil Engin Syst Saf 2015; 141: 22-32. 
7. Dessavre DG, Ramirez-Marquez JE, Barker K. Multidimensional approach to complex system resilience analysis. Reliabil Eng Syst Saf 2016; 149: 34-43.

8. Cutter SL. The landscape of disaster resilience indicators in the USA. Natl Hazards 2016; 80(2): 741-58.

9. Cutter SL, Burton CG, Emrich CT. Disaster resilience indicators for benchmarking baseline conditions. J Homeland Security Emerg Manag 2010; 7(1): 51 .

10. Bastaminia A, Rezaie MR, Saraie MH. Explaining and analyzing the concept of resiliency and its indicators and frameworks in natural disasters. Disast Prev Manag Knowl 2016; 6(1): 32-46 [In Persian].

11. Cutter SL, Barnes L, Berry M, Burton C, Evans E, Tate E, et al. A place-based model for understanding community resilience to natural disasters. Global Environ Change 2008; 18(4): 598606.

12. Sharifi A, Yamagata Y. Resilient urban planning major principles and criteria. Energy Proc 2014; 61: 1491-5.

13. Amini Hosseini K, Hosseini M, Jafari MK, Hosseinioon S. Recognition of vulnerable urban fabrics in earthquake zones: a case study of the Tehran metropolitan area. J Seismol Earthquake Eng 2020; 10(4): 175-87 [In Persian].

14. Rezaie MR, Rafieian M, Hosseini SM. Measurement and evaluation of physical resilience of urban communities against earthquake (Case study: Tehran neighborhoods). Hum Geography Res 2015; 47(4): 609-23 [In Persian].

15. Hosseini KA, Hosseinioon S. A survey on the parameters affecting the vulnerability of urban fabrics to earthquake in Tehran. 15th World Conference on Earthquake Engineering (15WCEE), Lisbon, Portugal; 2012. P. 24-8.

16. Eshgi A, Nazmfar H, Jafari A. Assessing the physical resilience of a city against possible earthquakes (Case Study: region one of Tehran). Phys Sac Plan 2018; 4(4): 11-26 [In Persian].

17. Ghahroudi Tali M, Pourmousavi SM, Khosravi S. Study of potential seismicity damage by multi attribute decision making (Case study: district 1 of Tehran). Quant Geomorphol Res 2013; 1(3): 57-68 [In Persian].

18. Setayeshi Nasaz H, Rostai SH, Omranidorbash M, Zarepishe M. Investigation of geomorphological limitations and its effect on physical growth of the city using GIS and AHP (Case study: Givi city). Quantit Geomorphol Res 2015; 4: 1-16[In Persian].

19. Maghsoudi M, Nayyeri H, Amani K. Hydrodynamics and stability of the Gheshlagh river and its effect on urban development in Sanandaj. Quantit Geomorphol Res 2018; 5(2): 66-81[In
Persian].

20. Parvin M. Evaluation of the interaction between geomorphologic and urban development conditions (Case study: Kermanshah city). Quantit Geomorphol Res 2019; 7(3): 231-44 [In Persian].

21. Aslani F, Amini-Hosseini K, Fallahi A. Evaluation of physical resilience of Karaj City, Iran, against earthquake. Sci J Rescue Reli 2019; 11: 63-71.

22. Rahimi F, Sadeghi Niaraki A, Qodousi, M. Modeling physical-social resilience in district 1 of Tehran. Quart Sci J Rescue Reli 2020; 12(1): 46-56 [In Persian].

23. Mohammadkhani M, Karkehabadi Z, Arghan A. Resilience assessment of Semnan, Iran, in the face of an earthquake. Quart Sci J Rescue Reli 2020; 12(3): 217-26 [In Persian].

24. Ramesht $\mathrm{MH}$. Chaos theory in geomorphology. Geography Dev Iran J 2003; 1(1): 13-37 [In Persian].

25. Ahern J. Urban landscape sustainability and resilience: the promise and challenges of integrating ecology with urban planning and design. Landscape Ecol 2013; 28(6): 1203-12.

26. Zare S, Hosseini F. The prevalence of urban areas vulnerability to seismic risk (a case study of region one, Tehran). Iran Univ Sci Technol 2017; 27(2): 153-60.

27. Hyogo framework for action 2005-2015: building the resilience of nations and communities to disasters. World Conference on Disaster Reduction, Hyogo, Japan; 2005.

28. Pearson L, Pelling M. The UN Sendai framework for disaster risk reduction 2015-2030: Negotiation process and prospects for science and practice. $\mathrm{J}$ Extreme Events 2015; 2(01): 1571001.

29. Tehran Master Plan. Ministry of roads \& urban development Islamic Republic of Iran. Tehran: Tehran Municipality; 2006 [In Persian].

30. The third 5-year plan. Tehran: Urban Renewal Organization of Tehran; 2019 [In Persian].

31. Ahmadabadi A, Saberi M. An application of quantitative geomorphometric indicators in identifying '[Susceptible Zones by Using SVM Model (Case study: Khorramabad-Pol Zal Freeway). Quanti Geomorphol Res 2016; 3: 197213.

32. Diao C. An approach to theory and methods of urban geomorphology. Chin Geographical Sci 1995; 6(1): 88-95.

33. Arc Map 10.3. ArcGIS Desktop. Available at: URL:https://desktop.arcgis.com/en/arcmap/10.3/main/ get-started/whats-new-in-arcgis-1031.htm; 2020.

34. Pashapoor H, Pourakrami M. Measuring physical dimensions of urban resilience in the face of the natural disasters (Earthquake) (Case study: Tehran's 12th District). J Stud Hum Settlements Plan 2018; 12(4): $985-1001$. 
35. Eshghei A, Nazmfar H. Assessment of urban resilience against earthquake by using promethee model, case study: district 1 of Tehran Municipality. J Urban Ecol Res 2019; 10(20): 12740.

36. Hosseini A, Fatahiyan SA, Malakan J. Spatial analysis of safe areas based of earthquake risk using multi-criteria decision making and fuzzy logic (The case study on district 20 of Tehran). J Environ Sci Technol 2020; 22(1): 151-66.

37. Pourahmad A, Ziyari K, Sadeghi A. Spatial analysis of physical resilience components of urban attrited/beaten tissues against earthquakes (Case study: district 10 of Tehran Municipality). J Spatial Plan 2018; 8(1): 110-30.
38. Derafshi K. The flood risk changes effective factors in Tehran Metropolis. J Spatial Analysis Environ Hazarts 2020; 7(3): 125-46.

39. Moghadas M, Asadzadeh A, Vafeidis A, Fekete A, Kötter T. A multi-criteria approach for assessing urban flood resilience in Tehran, Iran. Int J Disast Risk Reduct 2019; 35: 101069.

40. Masnavi MR, Gharai F, Hajibandeh M. Exploring urban resilience thinking for its application in urban planning: a review of literature. Int J Environ Sci Technol 2019; 16(1): 567-82.

41. Cariolet J M, Vuillet M, Diab Y. Mapping urban resilience to disasters-A review. Sustainable Cities Soc 2019; 51: 101746. 